Article

\title{
Impact of Black Carbon on Surface Ozone in the Yangtze River Delta from 2015 to 2018
}

\author{
Yue Tan ${ }^{1}$ (D), Delong Zhao ${ }^{2, *}$, Honglei Wang ${ }^{1,3, *}$, Bin Zhu ${ }^{1}$, Dongping Bai ${ }^{1}$, Ankang Liu ${ }^{1}$, Shuangshuang Shi ${ }^{1}$ \\ and Qihang Dai ${ }^{1}$
}

check for updates

Citation: Tan, Y.; Zhao, D.; Wang, H.; Zhu, B.; Bai, D.; Liu, A.; Shi, S.; Dai, Q Impact of Black Carbon on Surface Ozone in the Yangtze River Delta from 2015 to 2018. Atmosphere 2021, 12, 626. https://doi.org/ $10.3390 /$ atmos 12050626

Academic Editor: Pasquale Avino

Received: 12 April 2021

Accepted: 10 May 2021

Published: 13 May 2021

Publisher's Note: MDPI stays neutral with regard to jurisdictional claims in published maps and institutional affiliations.

Copyright: (c) 2021 by the authors. Licensee MDPI, Basel, Switzerland. This article is an open access article distributed under the terms and conditions of the Creative Commons Attribution (CC BY) license (https:// creativecommons.org/licenses/by/ $4.0 /)$.
1 Collaborative Innovation Center on Forecast and Evaluation of Meteorological Disasters, Key Laboratory for Aerosol-Cloud-Precipitation of China Meteorological Administration, Nanjing University of Information Science \&Technology, Nanjing 210044, China; tanyue_focus@163.com (Y.T.); binzhu@nuist.edu.cn (B.Z.); dongpingbai@hotmail.com (D.B.); 20181203017@nuist.edu.cn (A.L.); sss@nuist.edu.cn (S.S.); qihang.dai@student.manchester.ac.uk (Q.D.)

2 Beijing Weather Modification Office, Beijing 100089, China

3 Department of Geography and Planning, University of Toronto, Toronto, ON M5S3G3, Canada

* Correspondence: zhaodelong@bj.cma.gov.cn (D.Z.); hongleiwang@nuist.edu.cn (H.W.)

\begin{abstract}
Despite the yearly decline in $\mathrm{PM}_{2.5}$ in China, surface ozone has been rapidly increasing recently, which makes it imperative to coordinate and control both $\mathrm{PM}_{2.5}$ and ozone in the atmosphere. This study utilized the data of pollutant concentrations and meteorological elements during 2015 to 2018 in Nanjing, China to analyze the daily correlation between black carbon and ozone (CBO), and the distribution of the pollutant concentrations under different levels of CBO. Besides, the diurnal variations of pollutant concentrations and meteorological elements under high positive and negative $\mathrm{CBO}$ were discussed and compared. The results show that the percentage of positive $\mathrm{CBO}$ had been increasing at the average rate of $7.1 \%$ /year, and it was $38.7 \%$ in summer on average, nearly twice of that in other seasons (19.2\%). The average black carbon (BC), $\mathrm{PM}_{2.5}$ and $\mathrm{NO}_{2}$ under positive $\mathrm{CBO}$ was lower than those under negative $\mathrm{CBO}$. It is noticeable that the surface ozone began to ascend when $\mathrm{CBO}$ was up to 0.2 , with $\mathrm{PM}_{2.5}$ and $\mathrm{NO}_{2}$ decreasing and $\mathrm{BC}$ remaining steady. Under negative $\mathrm{CBO}$, pollutant concentrations and meteorological elements showed obvious diurnal variations: $\mathrm{BC}$ showed a double-peak pattern and surface ozone, $\mathrm{PM}_{2.5}, \mathrm{SO}_{2}$ and $\mathrm{CO}$ showed single-peak patterns and $\mathrm{NO}_{2}$ showed a trough from 10:00 to 19:00. Wind speed and visibility showed a single-peak pattern with little seasonal difference. Relative humidity rose first, then it lowered and then it rose. Under positive $\mathrm{CBO}$, the patterns of diurnal variations became less obvious, and some of them even showed no patterns, but just fluctuated at a certain level.
\end{abstract}

Keywords: black carbon; ozone; correlation between black carbon and ozone (CBO)

\section{Introduction}

Ozone is an integral trace component of the natural atmosphere, distributed mostly at the height of $10-30 \mathrm{~km}$ in the stratosphere and partly $(10 \%)$ in the troposphere. Although the ozone in the stratosphere can absorb almost all the solar ultraviolet radiation in the $0.2-0.3 \mu \mathrm{m}$ band so as to protect human skin from such harmful radiation, the surface ozone in the troposphere would pose a great threat to the human health, vegetation, crops and even buildings [1]. Recent studies have found that long term of exposure to the ozone would cause a significant increase in the mortality due to respiratory diseases [2]. With the surface ozone concentrations rising, the productivity of cotton, rice and wheat would all decrease [3]. So, it is imperative to control the ozone in the troposphere. The sources of tropospheric ozone are divided into natural sources and anthropogenic sources. The natural sources are mainly from photochemical reactions [4,5] and stratospheric input [6,7]. The anthropogenic sources mainly include transportation, integrated petrochemical industry, and smoke plumes from coal-fired power plants [8-11]. Apart from the sources, 
tropospheric ozone is also affected by the meteorological elements. A study found that the overwhelming factor of the surface ozone in western China is temperature using the Generalized Additive Models (GAM) [12], while the research carried out with the Community Multiscale Air Quality (CMAQ) modeling system showed that the main influencing factor of tropospheric ozone in most parts of China is the change of wind field. In addition, humidity, boundary layer height, cloud shape, and precipitation have obvious effects on tropospheric ozone [13].

Black carbon (BC) is the carbonaceous substance of $\mathrm{PM}_{2.5}$ and one of the absorbers of the visible light in the atmosphere. The main emission sources are biomass burning, the combustion of civil fuel and the transportation source [14]. Similar to ozone, BC also poses a great threat to humans health. Various toxic and harmful substances are easily absorbed onto the surface of black carbon due to its loose and porous structure. These harmful substances would affect human health when they are sucked into the respiratory tract and reach the lung together with BC [15-17]. Therefore, it is also imperative to reduce black carbon in the atmosphere. In recent years, China has continuously launched a series of governance programs to control black carbon and organic carbon, which have already been showing positive outcomes. For example, the black carbon (BC) and organic carbon (OC) in urban areas of Beijing have been reduced by nearly half between 2013 and 2018 , to $7.7 \mu \mathrm{g} \cdot \mathrm{m}^{-3}$ and $2.6 \mu \mathrm{g} \cdot \mathrm{m}^{-3}$, respectively, which is closely related to the air pollution prevention and control measures. However, the results in Beijing, of the air pollution prevention and control measures, are far from comparable to those of major cities in developed countries, such as Los Angeles $\left(2.9 \mu \mathrm{g} \cdot \mathrm{m}^{-3}\right.$ for BC and $0.6 \mu \mathrm{g} \cdot \mathrm{m}^{-3}$ for OC) and Tokyo $\left(2.2 \mu \mathrm{g} \cdot \mathrm{m}^{-3}\right.$ for BC and $0.6 \mu \mathrm{g} \cdot \mathrm{m}^{-3}$ for OC) [18], indicating that China still has the potential for controlling carbonaceous pollutants in the atmosphere. BC concentrations are also affected by meteorological elements. One of the recent studies shows that BC is inversely proportional to temperature and wind speed and directly proportional to relative humidity [19]. However, some other studies claim that BC is inversely proportional to temperature, wind speed, relative humidity, visibility, and precipitation [20]. This indicates that more research should be carried out before the relationship between meteorological elements and BC is clear enough.

Ozone and $\mathrm{BC}$ are closely correlated in the atmosphere because of the light absorption of black carbon [21-23] and the photosensitivity of the ozone generation mechanism [24,25]. The impacts of $\mathrm{BC}$ on photochemistry in the atmosphere, which generates ozone, are significant in polluted urban areas. Unlike most cooling aerosols, by increasing the surface reflectivity, $\mathrm{BC}$ absorbs the solar radiation and warms the atmosphere and the surface of the Earth, which in turn influences photochemistry. A case study conducted in Houston in 2000 has found that $\mathrm{BC}$ aerosols can reduce the photolysis frequencies of $\left.\mathrm{J}_{[0}\left(\mathrm{O}_{3} \mathrm{D}\right)\right]$ in the boundary layer, and in turn, the concentrations of the surface ozone [26]. However, a recent study found that the BC-boundary layer interactions can offset the decrease of ozone, because of the reduced photolysis rate, and enhance ozone formation [27]. So, the correlation between BC and ozone is complex and worth further research. In most cases, ozone is negatively related with black carbon, which makes the comprehensive management of both ozone pollution and black carbon pollution difficult. In recent years, the main pollution level in China has dropped significantly due to people's growing attention to the air quality and the government's effective measures taken to combat it. However, concerned authorities are focusing more on the control of inhalable particulate matter $\left(\mathrm{PM}_{2.5}\right)$ than on ozone pollution. With $\mathrm{PM}_{2.5}$ declining overall in most parts of eastern China, surface ozone levels are on the rise [28-30]. Recent years have seen many ozone pollution incidents, one of which was in the summer in 2017. In this ozone pollution episode, most parts of China experienced severe surface ozone pollution, with 30 of China's 74 major cities studied having the proportion of $90 \%$ that maximum $8 \mathrm{~h}$ average (MDA8) ozone level exceeded $200 \mu \mathrm{g} \cdot \mathrm{m}^{-3}$ [31]. Therefore, how to coordinately control $\mathrm{PM}_{2.5}$ and ozone pollution in the atmosphere has become a difficult issue [32]. This paper mainly studies the effect of black carbon in the atmosphere on the formation of surface ozone. This 
study utilized data of pollutant concentrations ( $\mathrm{BC}, \mathrm{O}_{3}, \mathrm{PM}_{2.5}, \mathrm{PM}_{10}, \mathrm{CO}, \mathrm{NO}_{2}$ and $\mathrm{SO}_{2}$ ) and meteorological elements during 2015 to 2018 in Nanjing, China to analyze the daily correlation between black carbon and ozone (CBO), and the distribution of the pollutant concentrations under different levels of $\mathrm{CBO}$. Besides, the diurnal variations of pollutant concentrations and meteorological elements under high positive $\mathrm{CBO}$ and negative $\mathrm{CBO}$ were also discussed and compared.

\section{Data and Methods}

\subsection{Sampling Area and Time}

In this research, the sampling area was located on the top of the meteorological building on the campus of Nanjing University of Information Science and Technology (NUIST, $32.207^{\circ} \mathrm{N}, 118.717^{\circ} \mathrm{E}$ ), at the altitude of $60 \mathrm{~m}$. There are numeric roads around the sampling site, which means transportation is developed. To the northeast of the sampling area is an industrial zone, which includes petrochemical, steel and chemical energy polluting enterprises. The sampling time of this study is from 1 January 2015 to 31 December 2018. More details can be seen in our previous research [30].

\subsection{Observation Instruments and Methodology}

Black carbon was measured with the Model AE-33 aethalometer (Magee Scientific, Berkeley, CA, USA), which uses two-point measurement technology and dynamic zeropoint calibration to provide continuous observations at fixed points at seven wavelengths $(370,470,520,590,660,880,950 \mathrm{~nm})$. Because the absorption characteristics of other light-absorbing aerosols (e.g., brown carbon and mineral dust) at $880 \mathrm{~nm}$ are not obvious, the data measured at $880 \mathrm{~nm}$ are taken as the mass concentrations of BC [33]. The Model AE-33 aethalometer uses $\mathrm{PM}_{2.5}$ cutting heads with a sampling flow of $5 \mathrm{~L} / \mathrm{min}$ and a time resolution of $1 \mathrm{~min}$. Moreover, data of the mass concentrations of other air pollutants $\left(\mathrm{PM}_{2.5}\right.$, $\mathrm{PM}_{10}, \mathrm{NO}_{2}, \mathrm{SO}_{2}, \mathrm{CO}$ and $\mathrm{O}_{3}$ ) were provided by the national real-time publishing platform for urban air quality (http:/ 106.37.208.233:20035/, accessed 11 May 2021). Meteorological elements (wind speed and direction, visibility, precipitation, etc.) are provided by the CAWSD600 automatic observation station on the campus of NUIST. More details can be seen in our previous research [30].

The Pearson correlation coefficient between black carbon and ozone (CBO) was calculated based on the 24-h data measured per hour in a day. Two types of data, where CBO is significantly positive $(\mathrm{CBO}>0.5)$ and significantly negative $(\mathrm{CBO}<-0.5)$, were selected from the database for further analysis, as shown in Figure 1.
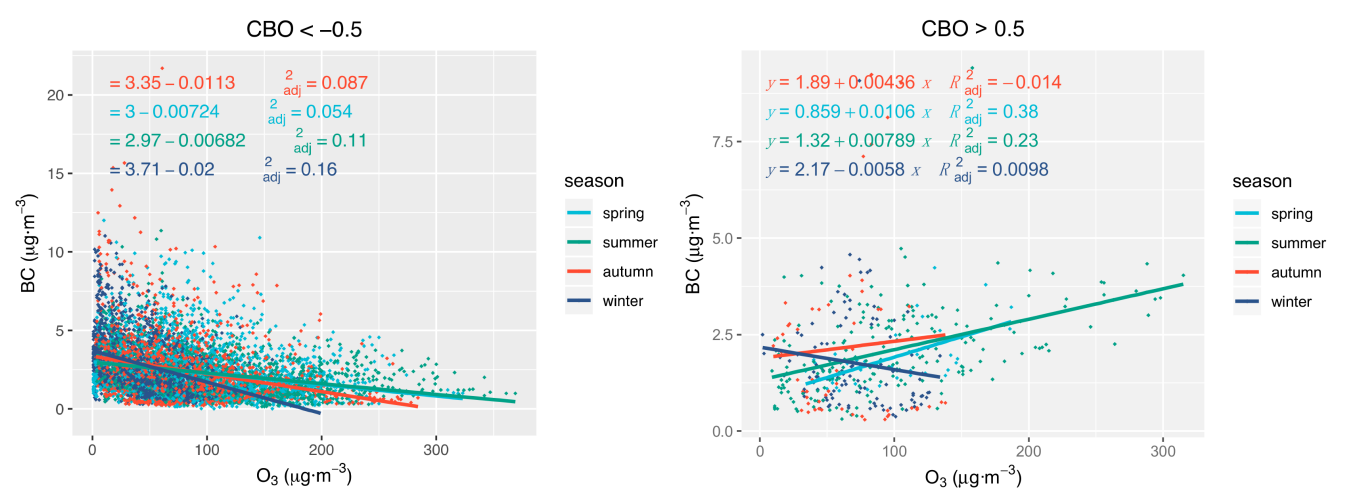

Figure 1. The scatter plot and the linear fit of $\mathrm{O}_{3}$ and $\mathrm{BC}$ concentrations.

Samples (6988) with significantly negative $\mathrm{CBO}$ collected are much more than those (403) with significant positive $\mathrm{CBO}$. It shows that $\mathrm{BC}$ and $\mathrm{O}_{3}$ are negatively correlated in most cases, but there are still some data where they are positively correlated, and this part of the data also needs attention. In the case of significant positive $\mathrm{CBO}$, the adjusted R-square in spring is larger, which means that the fitting result is better and the adjusted $\mathrm{R}$-square in autumn is negative, indicating that the fitting result is not ideal enough. 


\section{Results and Discussion}

\subsection{Frequency Analysis of $C B O$}

During the sampling time, from 2015 to 2018 , a total of 19,310 valid hourly samples for 955 days were obtained. In order to exclude the impact of wet deposition, we excluded the precipitation days, and got 83 days of positive $\mathrm{CBO}$, accounting for $14.0 \%$ of the total days, which is only about one-sixth of the days with negative $\mathrm{CBO}$ (532 days). As shown in Figure 2, the number of days with positive CBO from 2015 to 2018 were 16, 31, 16 and 20, respectively, accounting for $18.0 \%, 34.8 \%, 22.5 \%$ and $24.7 \%$ of the total observation days in that year. Among them, the number of days when $\mathrm{CBO}$ was over 0.5 were $3,7,4$ and 8 , accounting for $18.8 \%, 22.6 \%, 25.0 \%$ and $40.0 \%$ of the total days with positive CBO. It is notable that the proportion of high CBO had been increasing annually from 2015 to 2018, and the average increasing rate was $7.1 \%$ per year.

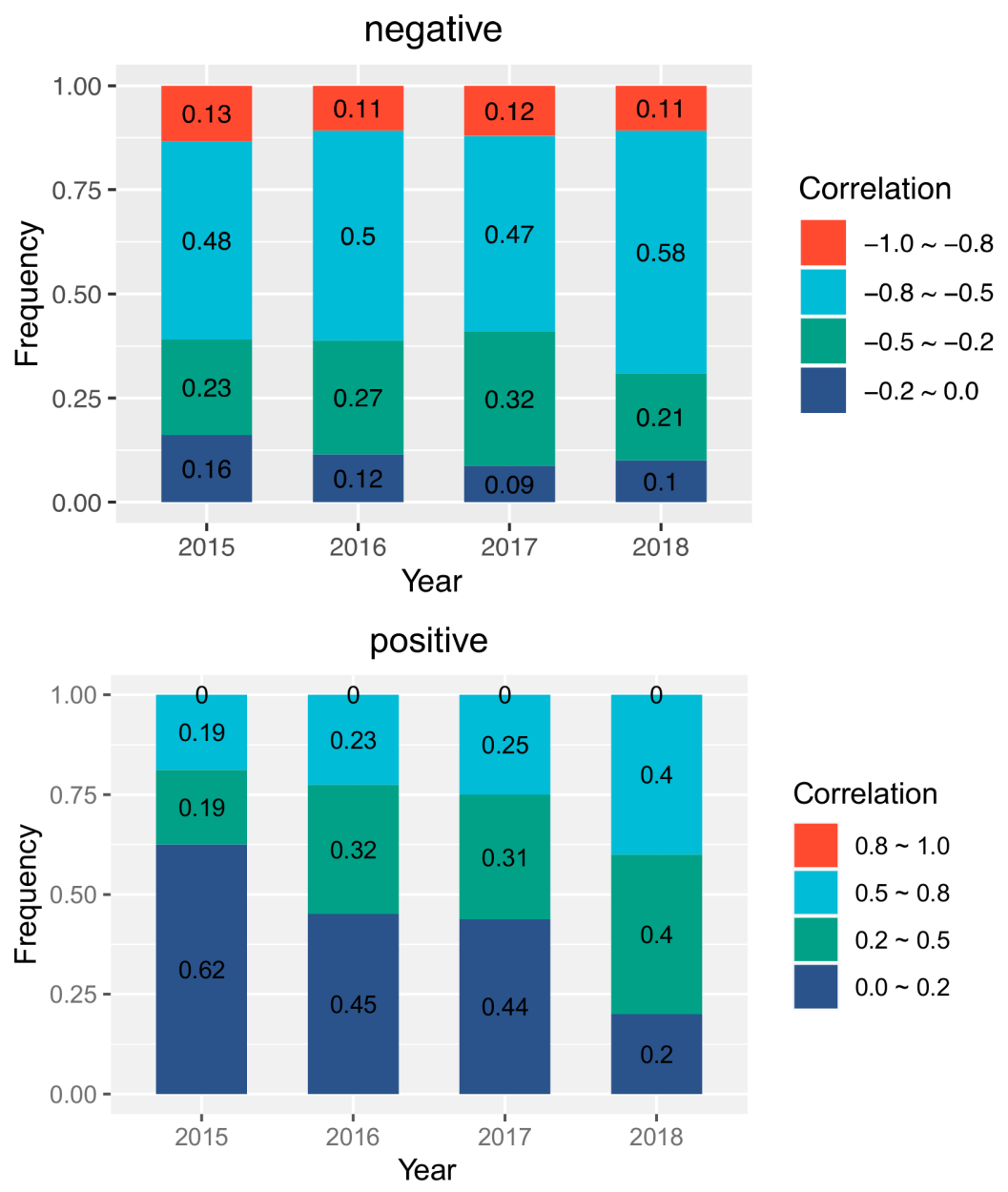

Figure 2. The annual variations of the frequency of negative $\mathrm{CBO}$ and positive $\mathrm{CBO}$.

Except for March, November and December, there are a considerable number of days in each month (Figure 3) when the mass concentrations of $\mathrm{BC}$ and $\mathrm{O}_{3}$ are showed to be significantly positive $\mathrm{CBO}(0.5<\mathrm{CBO}<0.8)$. Among these, June had the largest number, with a total of five days, accounting for $55.6 \%$ of the total days with positive $\mathrm{CBO}$ in this month. Furthermore, in October and August, days of significantly positive CBO accounted for about $50.0 \%$ and $40.0 \%$, respectively. Thus, although negative CBO was more common than positive correlations overall, there are considerable periods with significantly high positive $\mathrm{CBO}$. 

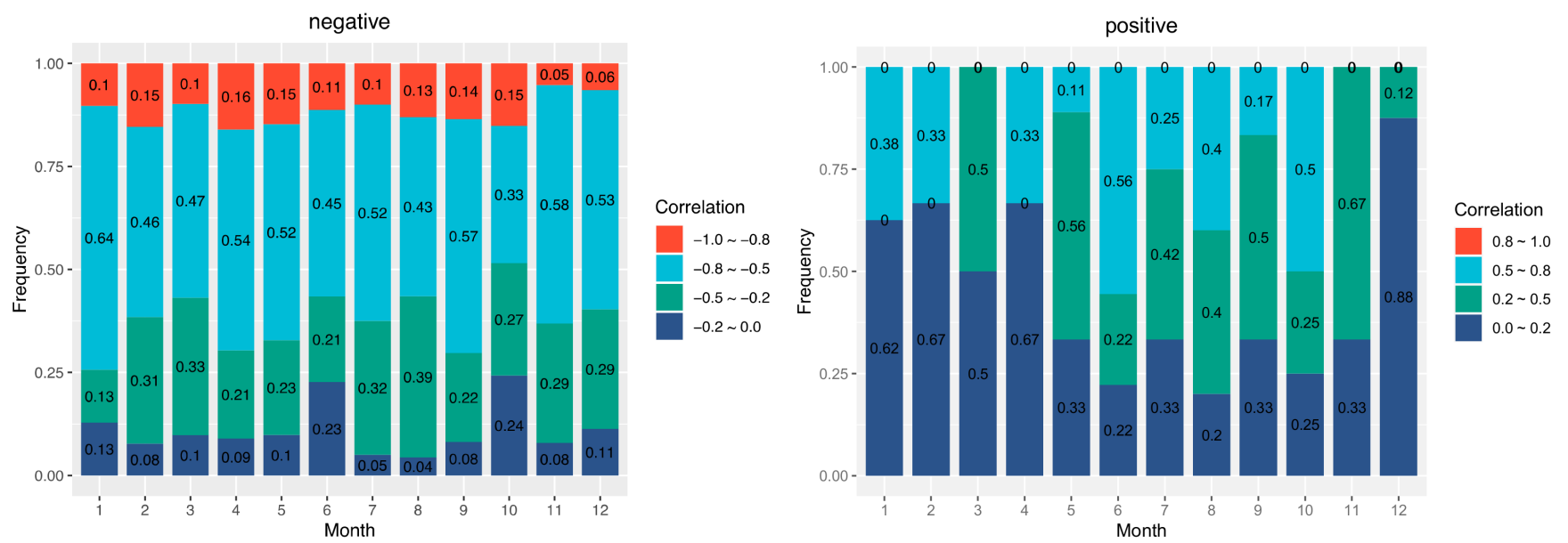

Figure 3. The monthly variations of the frequency of negative $\mathrm{CBO}$ and positive $\mathrm{CBO}$.

As for the seasonal variations (Figure 4), the proportion of significantly positive CBO $(0.5<\mathrm{CBO}<0.8)$ in summer was $38.7 \%$, higher than that in other seasons, while the proportion of strong positive correlations in the other seasons was merely mainly about $19.2 \%$, nearly half of that in summer.

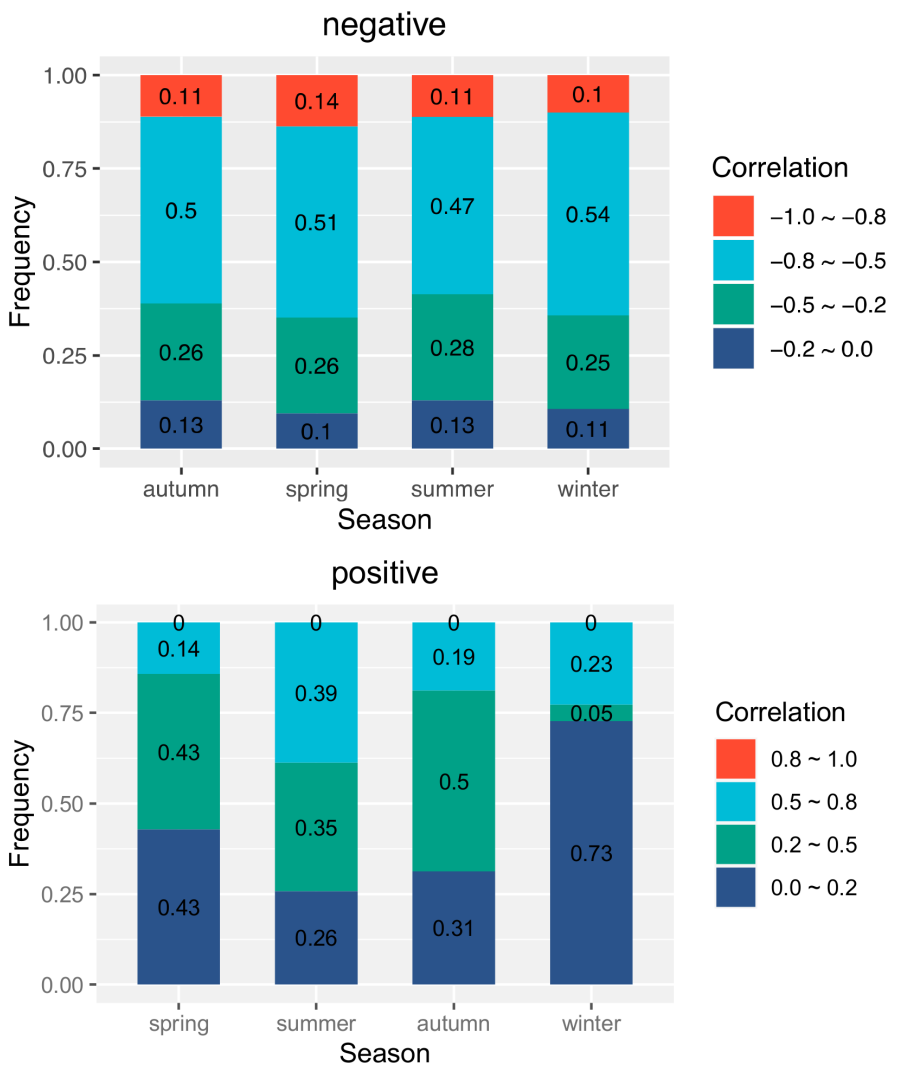

Figure 4. The seasonal variations of the frequency of negative $\mathrm{CBO}$ and positive $\mathrm{CBO}$.

\subsection{Distribution of Pollutants under Different Levels of $C B O$}

According to Figure 5, the distribution of $\mathrm{PM}_{2.5}, \mathrm{BC}, \mathrm{O}_{3}$ and $\mathrm{NO}_{2}$ varied greatly under different $\mathrm{CBOs}$. In the condition of positive $\mathrm{CBO}$, the average mass concentrations of $\mathrm{BC}$, $\mathrm{PM}_{2.5}$ and $\mathrm{NO}_{2}$ were 1.94, 38.51 and $35.52 \mu \mathrm{g} \cdot \mathrm{m}^{-3}$, respectively, and those on the occasion of negative CBO were significantly lower: $2.28,46.38$ and $44.44 \mu \mathrm{g} \cdot \mathrm{m}^{-3}$, respectively. The average mass concentration of ozone was very close for negative CBO $\left(81.56 \mu \mathrm{g} \cdot \mathrm{m}^{-3}\right)$ and positive $\mathrm{CBO}\left(81.14 \mu \mathrm{g} \cdot \mathrm{m}^{-3}\right)$. It is worth noting that when $\mathrm{CBO}$ was above 0.2 , the 
surface ozone began to rise significantly, with $\mathrm{PM}_{2.5}$ and $\mathrm{NO}_{2}$ decreasing significantly and $\mathrm{BC}$ stable. According to Figure $\mathrm{S} 1$, the distribution of $\mathrm{SO}_{2}, \mathrm{PM}_{10}, \mathrm{CO}$ and meteorological elements varied greatly under different $\mathrm{CBOs}$, too.

$\mathrm{BC}$

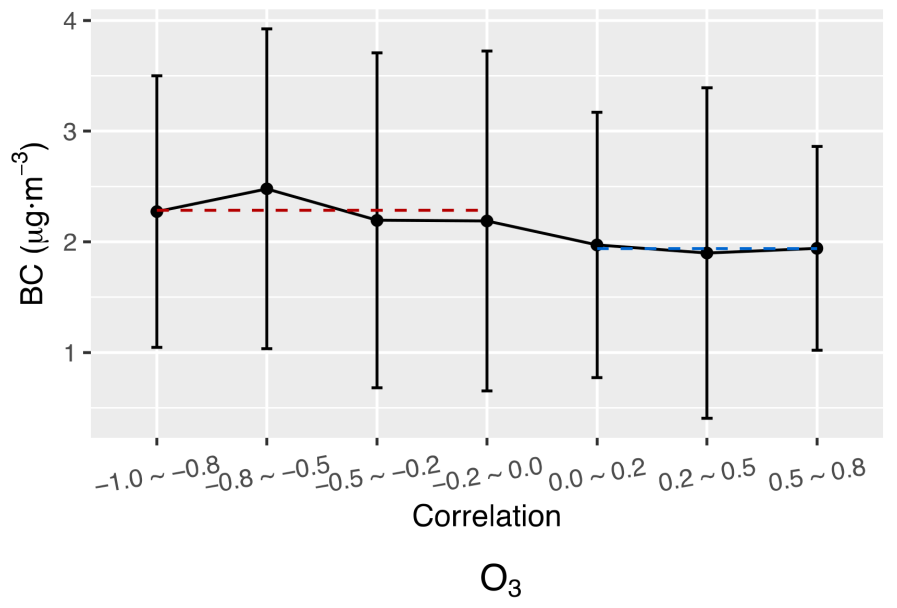

$\mathrm{PM}_{2.5}$
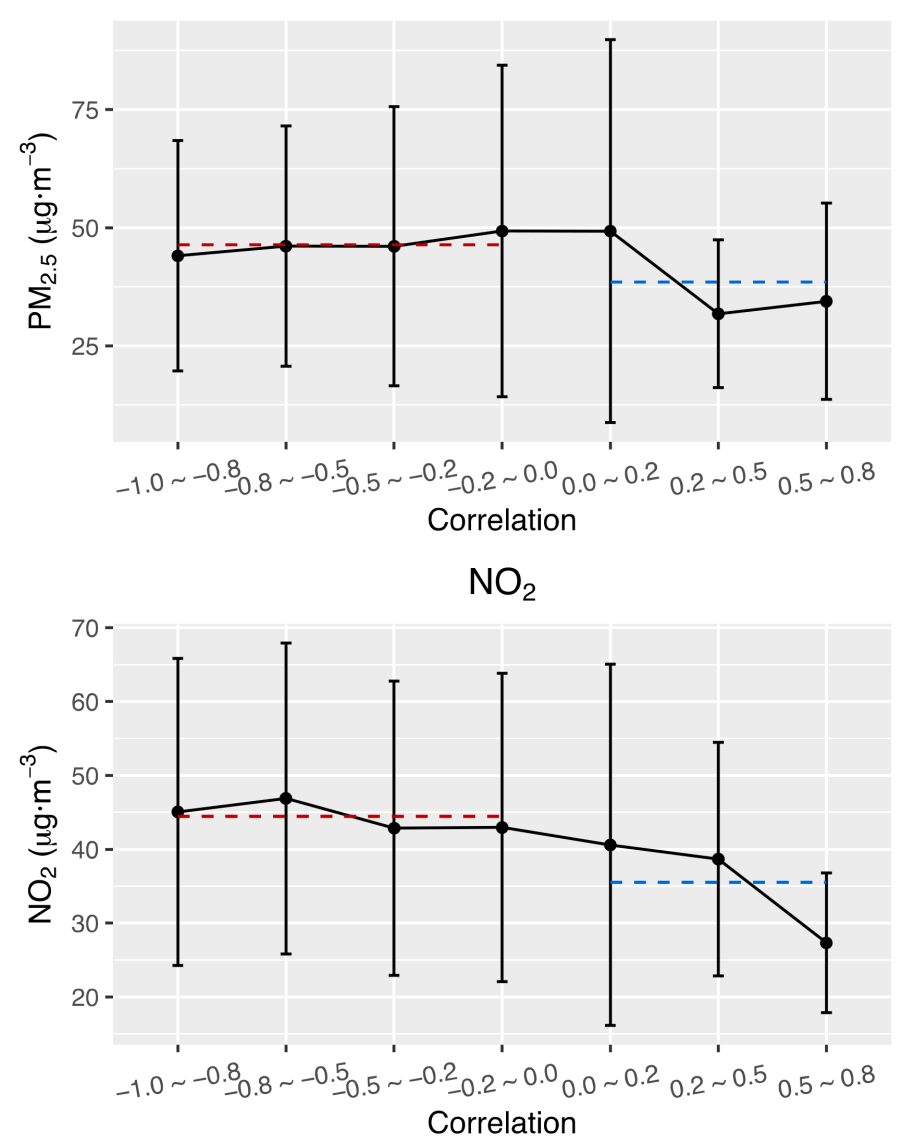

Figure 5. Mass concentrations of pollutants $\left(\mathrm{BC}, \mathrm{PM}_{2.5}, \mathrm{O}_{3}, \mathrm{NO}_{2}\right)$ under different levels of $\mathrm{CBO}$.

3.3. Diurnal Variations of Pollutants Concentrations and Metrological Elements under Significantly Positive and Negative $\mathrm{CBOs}$

3.3.1. Diurnal Variations of BC and Ozone

There are tremendous differences of diurnal variations of $\mathrm{BC}$ and ozone between significantly positive $\mathrm{CBO}$ and negative $\mathrm{CBO}$ :

As for $\mathrm{BC}$ (Figure 6), (1) while $-1.0<\mathrm{CBO}<-0.5$, the diurnal variations of $\mathrm{BC}$ concentrations showed a double peak pattern. $\mathrm{BC}$ rose slightly around the level of $3.0 \mu \mathrm{g} \cdot \mathrm{m}^{-3}$ during 0:00 to 5:00 and rapidly after sunrise, reaching the first peak at round 7:00-8:00, which were $3.36,3.37,3.75$ and $3.41 \mu \mathrm{g} \cdot \mathrm{m}^{-3}$ in spring, summer, autumn and winter, respectively. BC bottomed out to be around $1.40 \mu \mathrm{g} \cdot \mathrm{m}^{-3}$ at about 14:00, and afterwards, it began to increase and was approaching a steady value at dust. This coordinates with the results of most previous studies carried out in many regions [20,34-36]. (2) In contrast, while $0.5<\mathrm{CBO}<1.0$, mass concentration of $\mathrm{BC}$ was stable during 0:00-13:00, fluctuating slightly around $1.40 \mu \mathrm{g} \cdot \mathrm{m}^{-3}$, which was merely half of that $\left(3.0 \mu \mathrm{g} \cdot \mathrm{m}^{-3}\right)$ during the contemporaneous period of the counterpart situation. The trend of BC after 13:00 differed significantly in different seasons: In spring and summer BC rose slightly, reaching a slight peak of $2.64,3.03 \mu \mathrm{g} \cdot \mathrm{m}^{-3}$ at dusk, similar to that during the contemporaneous period of the counterpart situation. In autumn, BC increased rapidly after 13:00 and reached the highest level $\left(5.57 \mu \mathrm{g} \cdot \mathrm{m}^{-3}\right)$ of the whole day at 19:00. In winter, BC rose slowly overall and saw a sudden drop at 16:00 and 20:00, and a sudden increase at 21:00. 


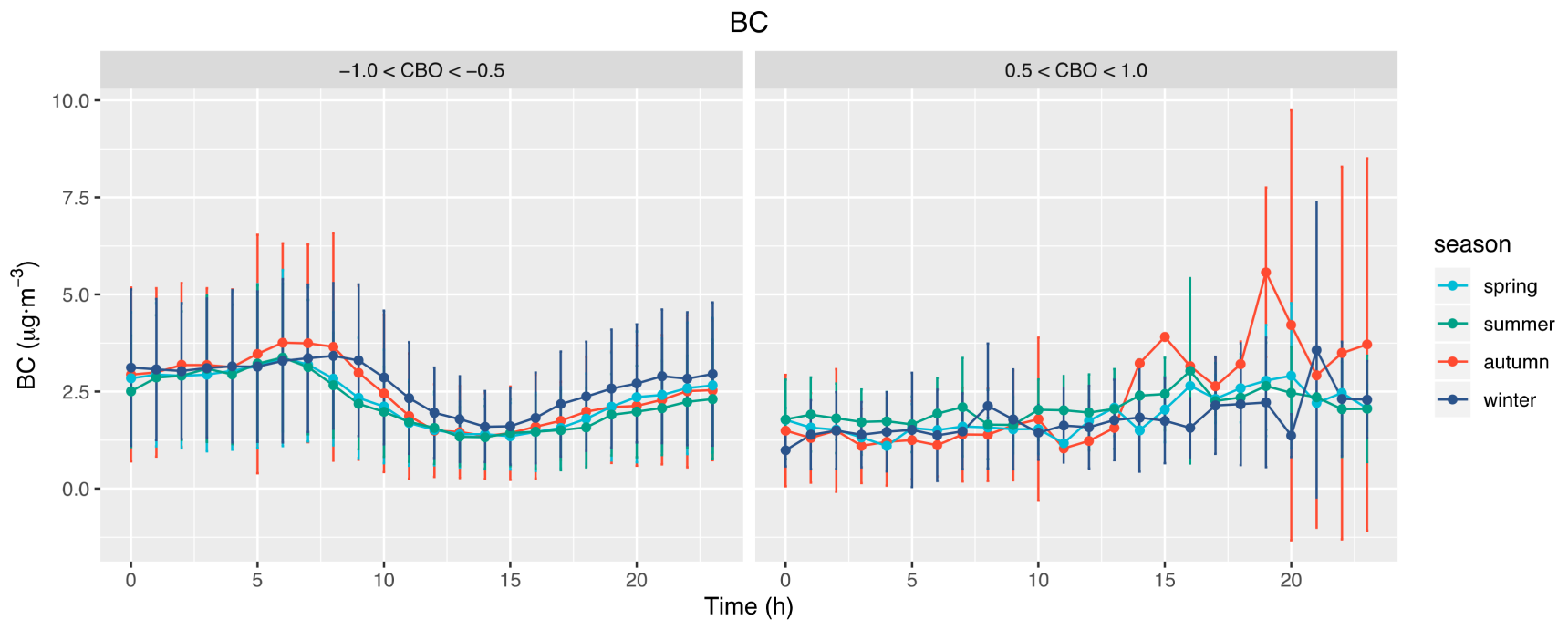

Figure 6. Diurnal variations of $\mathrm{BC}$ in two situations: (left): $-1.0<\mathrm{CBO}<-0.5$ and (right): $0.5<\mathrm{CBO}<1.0$.

As for $\mathrm{O}_{3}$ (Figure 7), (1) while $-1.0<\mathrm{CBO}<-0.5$, the diurnal variations of $\mathrm{O}_{3}$ concentrations showed a single peak pattern, which coordinated with the results from previous studies. $\mathrm{O}_{3}$ reached the peak at 15:00-16:00, which was 157.67, 202.46, 139.53, $86.62 \mu \mathrm{g} \cdot \mathrm{m}^{-3}$ in spring, summer, autumn and winter, respectively. (2) In contrast, while $0.5<\mathrm{CBO}<1.0$, the peak was $186.00,167.40,111.00$ and $99.00 \mu \mathrm{g} \cdot \mathrm{m}^{-3}$ in spring, summer, autumn and winter, respectively, about $118.0 \%, 82.7 \%, 79.6 \%$ and $114.3 \%$ of that for $-1.0<\mathrm{CBO}<-0.5$. The maximums in summer and autumn declined obviously compared with those for $-1.0<\mathrm{CBO}<-0.5$, while the maximums in spring and winter increased obviously compared with those for $-1.0<\mathrm{CBO}<-0.5$. It is noticeable that comparing both occasions, $\mathrm{O}_{3}$ in autumn differed greatly-the mass concentration of $\mathrm{O}_{3}$ during 11:00-19:00 for $0.5<\mathrm{CBO}<1.0$ was obviously lower that for $-1.0<\mathrm{CBO}<-0.5$, which may be due to the increased $\mathrm{BC}$ during the contemporaneous period in autumn.

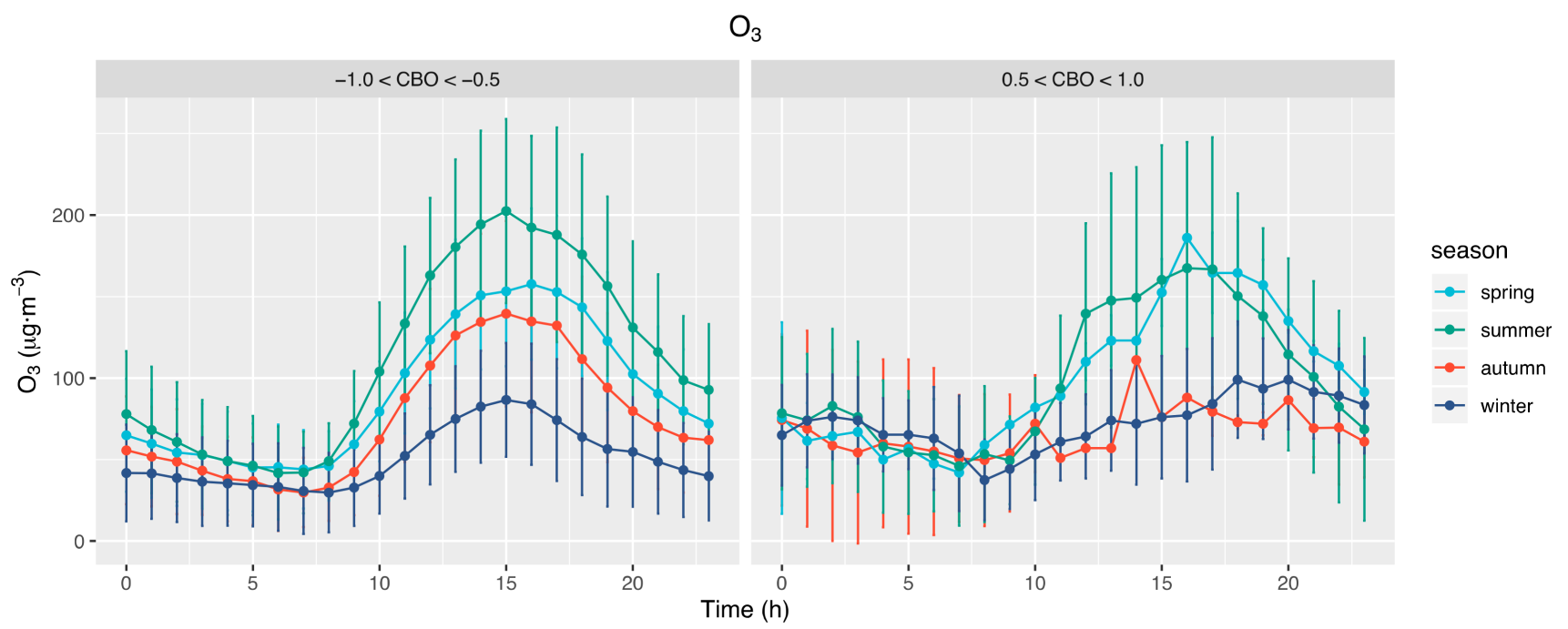

Figure 7. Diurnal variations of $\mathrm{O}_{3}$ in two situations: (left): $-1.0<\mathrm{CBO}<-0.5$ and (right): $0.5<\mathrm{CBO}<1.0$.

\subsubsection{Diurnal Variations of the Other Pollutants}

As for $\mathrm{PM}_{2.5}$ (Figure 8), (1) while $-1.0<\mathrm{CBO}<-0.5, \mathrm{PM}_{2.5}$ reached the peak at 9:00-10:00, which was 52.59, 36.69 and $49.43,78.27 \mu \mathrm{g} \cdot \mathrm{m}^{-3}$ in spring, summer, autumn and winter, respectively. $\mathrm{PM}_{2.5}$ was severer in winter than in the other seasons. Another feature of the diurnal variations of $\mathrm{PM}_{2.5}$ in winter is that it faced a strong reduction rate (approximately $6.88 \mu \mathrm{g} \cdot \mathrm{m}^{-3} \cdot \mathrm{h}^{-1}$ ) between 11:00 and 14:00 after peaking at 9:00-10:00 and 
it remained at a relatively low value after 15:00. In contrast, $\mathrm{PM}_{2.5}$ in the other three seasons showed similar trends as in winter, but the change was not so dramatic. (2) In contrast, while $0.5<\mathrm{CBO}<1.0$, the diurnal variations of $\mathrm{PM}_{2.5}$ concentrations in spring and winter showed a different trend from that for $-1.0<\mathrm{CBO}<-0.5$. It is noticeable that $\mathrm{PM}_{2.5}$ showed a continuous rising trend, especially after 11:00, different form the declining trend of $\mathrm{PM}_{2.5}$ for $-1.0<\mathrm{CBO}<-0.5$. Thus, $\mathrm{PM}_{2.5}$ peaked in spring at $67.00 \mu \mathrm{g} \cdot \mathrm{m}^{-3}$ at $18: 00$, and in winter at $97.50 \mu \mathrm{g} \cdot \mathrm{m}^{-3}$ at 23:00.

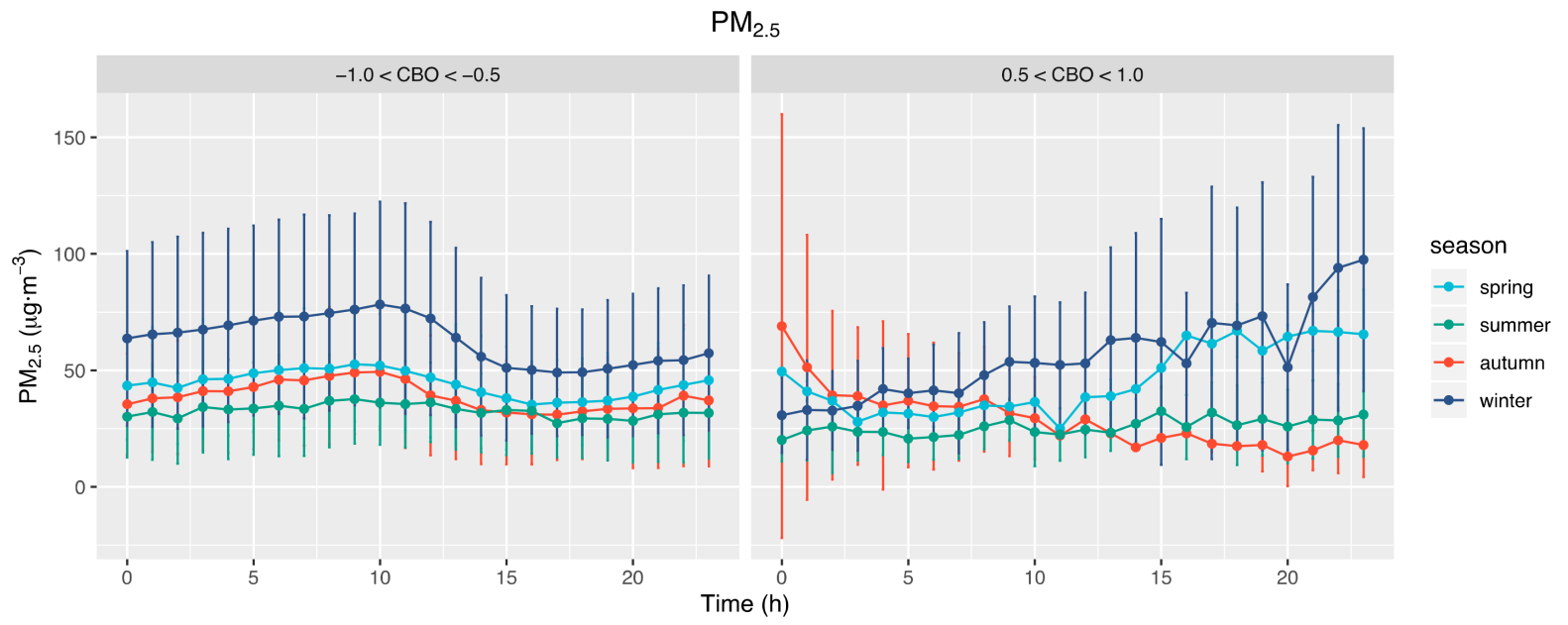

Figure 8. Diurnal variations of $\mathrm{PM}_{2.5}$ in two situations: (left): $-1.0<\mathrm{CBO}<-0.5$ and (right): $0.5<\mathrm{CBO}<1.0$.

As for $\mathrm{NO}_{2}$ (Figure 9), (1) while $-1.0<\mathrm{CBO}<-0.5$, the average $\mathrm{NO}_{2}$ was the highest in winter $\left(53.34 \mu \mathrm{g} \cdot \mathrm{m}^{-3}\right)$, and the lowest in summer $\left(33.74 \mu \mathrm{g} \cdot \mathrm{m}^{-3}\right)$, and the diurnal variations of $\mathrm{NO}_{2}$ had a trough between 10:00 and 19:00. (2) In contrast, while $0.5<\mathrm{CBO}<1.0$, the average $\mathrm{NO}_{2}$ was the highest in spring $\left(35.85 \mu \mathrm{g} \cdot \mathrm{m}^{-3}\right)$, and the lowest in winter $\left(20.50 \mu \mathrm{g} \cdot \mathrm{m}^{-3}\right)$. Overall, the $\mathrm{NO}_{2}$ concentration for $0.5<\mathrm{CBO}<1.0$ was lower than that for $-1.0<\mathrm{CBO}<-0.5$, and especially in winter, $\mathrm{NO}_{2}$ was merely $38.4 \%$ of that for $-1.0<\mathrm{CBO}<-0.5$. Another feather is that for all four seasons, while $0.5<\mathrm{CBO}<1.0$, $\mathrm{NO}_{2}$ fluctuated at a certain level instead of showing any apparent troughs throughout the day.

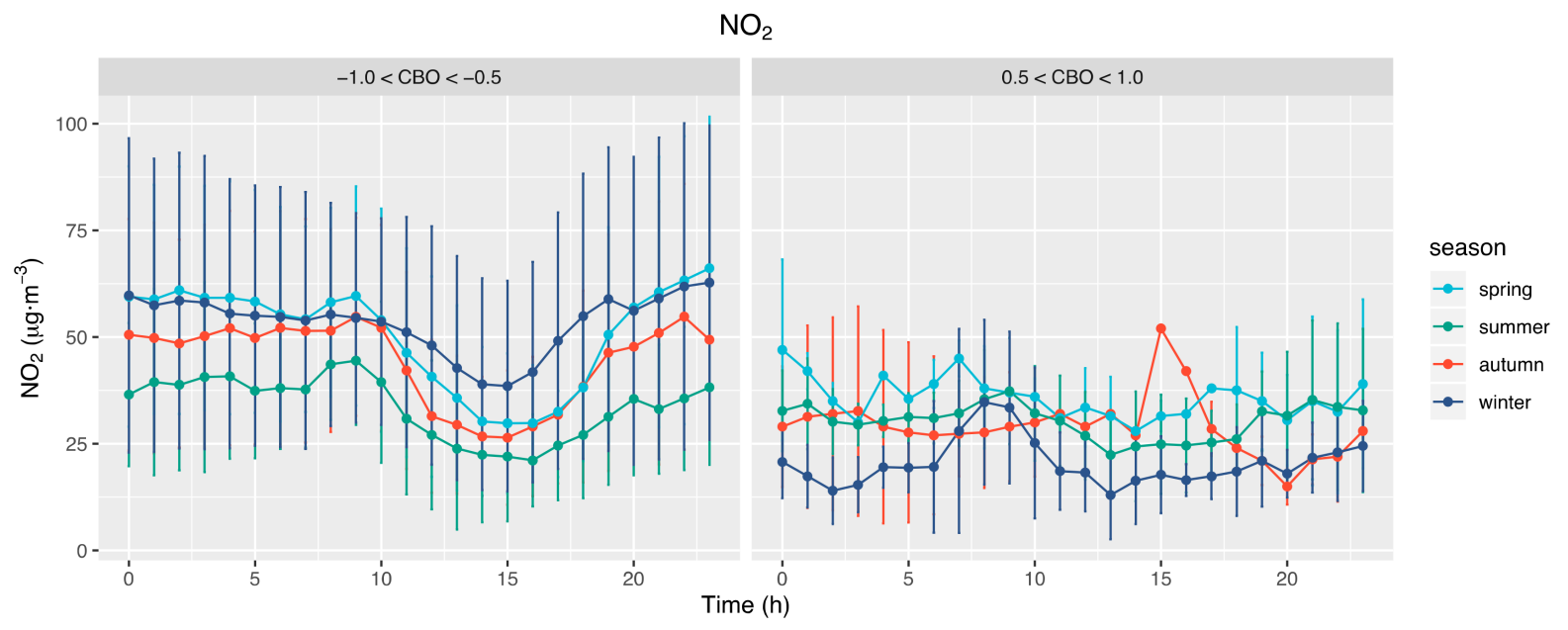

Figure 9. Diurnal variations of $\mathrm{NO}_{2}$ in two situations: (left): $-1.0<\mathrm{CBO}<-0.5$ and (right): $0.5<\mathrm{CBO}<1.0$.

As shown in Figure 10, In both cases $(-1.0<\mathrm{CBO}<-0.5$ and $0.5<\mathrm{CBO}<1.0)$, the difference in $\mathrm{SO}_{2}$ mass concentrations was not significant, and in winter, $\mathrm{SO}_{2}$ was slightly lower for $-1.0<\mathrm{CBO}<-0.5$ than for $0.5<\mathrm{CBO}<1.0$. 


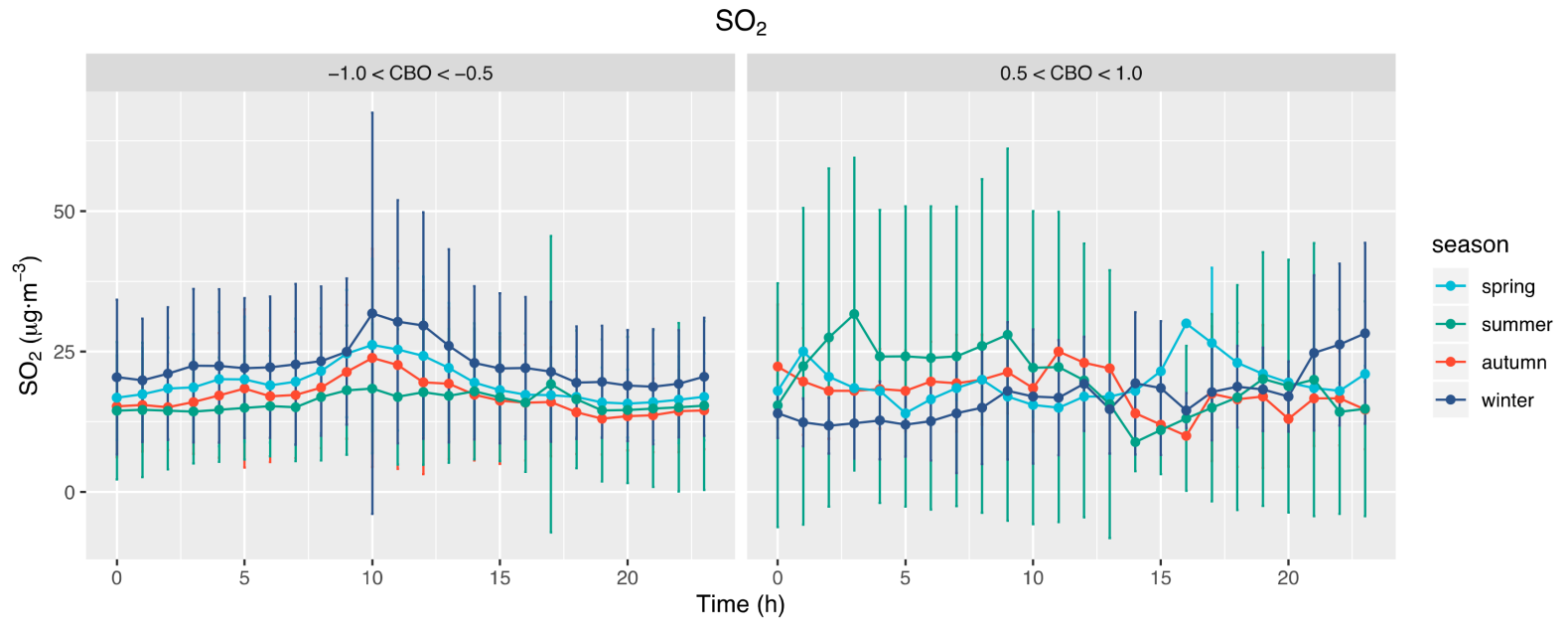

Figure 10. Diurnal variations of $\mathrm{SO}_{2}$ in two situations: (left): $-1.0<\mathrm{CBO}<-0.5$ and (right): $0.5<\mathrm{CBO}<1.0$.

As for $\mathrm{CO}$ (Figure 11), (1) while $-1.0<\mathrm{CBO}<-0.5$, the diurnal variations of $\mathrm{CO}$ concentrations showed a single peak pattern, peaking at around 10:00-11:00. Compared with the other seasons, $\mathrm{CO}$ in winter was the highest on average $\left(1.12 \mu \mathrm{g} \cdot \mathrm{m}^{-3}\right)$. (2) While $0.5<\mathrm{CBO}<1.0, \mathrm{CO}$ concentration was also the highest on average in winter $\left(1.14 \mu \mathrm{g} \cdot \mathrm{m}^{-3}\right)$, and $\mathrm{CO}$ in spring and summer was slightly lower than that for $-1.0<\mathrm{CBO}<-0.5$. As for the diurnal variations, while $0.5<\mathrm{CBO}<1.0$, $\mathrm{CO}$ did not show the single peak pattern as was shown while $-1.0<\mathrm{CBO}<-0.5$. $\mathrm{CO}$ was overall higher during 15:00-23:00 than 0:00-14:00.

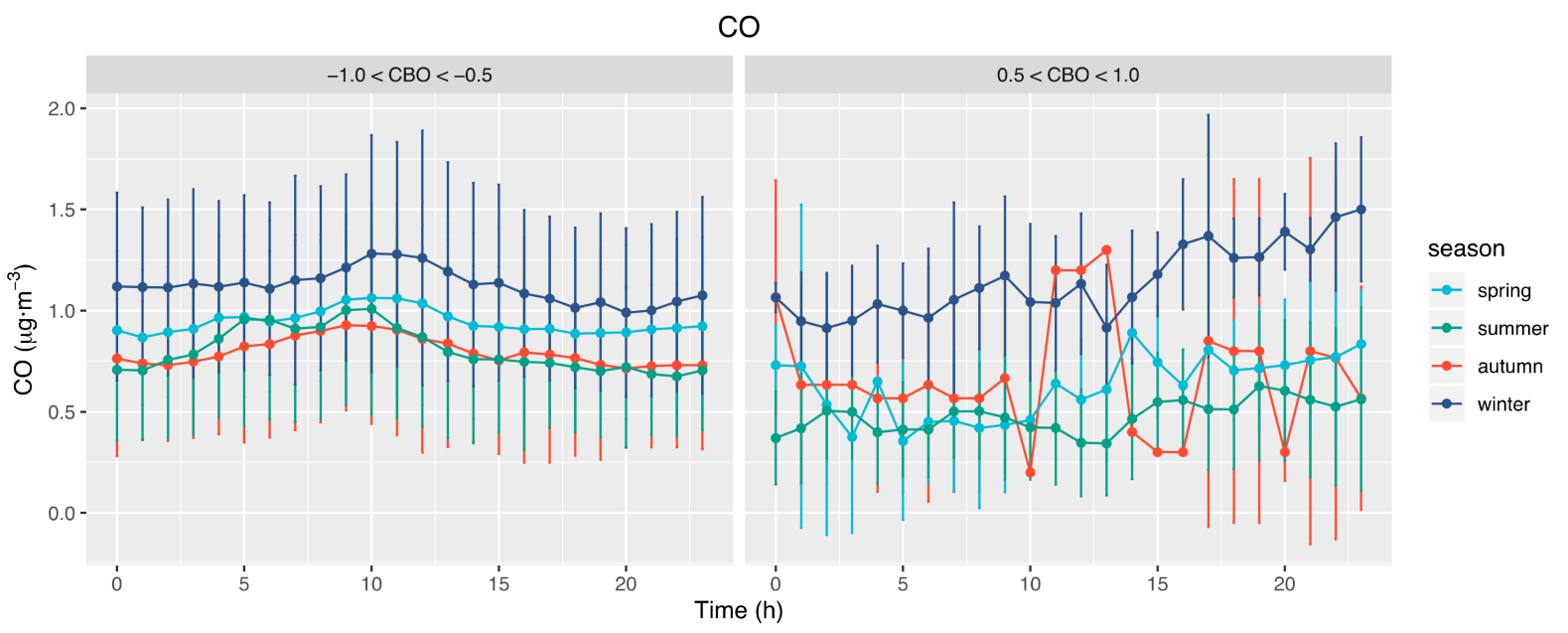

Figure 11. Diurnal variations of $\mathrm{CO}$ in two situations: (left): $-1.0<\mathrm{CBO}<-0.5$ and (right): $0.5<\mathrm{CBO}<1.0$.

\subsubsection{Diurnal Variations of Meteorological Elements}

Recent research studies have studied the effects of meteorological elements on the formation of $\mathrm{O}_{3}$ with WRF-CMAQ model. One of these research studies has found that, among a series of meteorological elements, the change of wind speed had the most significant effect on the maximum daily $8 \mathrm{~h}$ average (MDA8) $\mathrm{O}_{3}$ [13]. In this research, the average value and the diurnal variations of wind speed differed under different $\mathrm{CBO}$ s. As is shown in Figure 12, (1) while $-1.0<\mathrm{CBO}<-0.5$, wind speed showed a single peak pattern, reaching a peak (around $2.68 \mathrm{~m} \cdot \mathrm{s}^{-1}$ ) at round 14:00. In such a situation, the seasonal differences of diurnal variations of wind speed were not obvious, except for the wind speed during 0:00-8:00 (spring $\approx$ winter $>$ summer $>$ autumn). (2) While $0.5<\mathrm{CBO}<1.0$, the overall average wind speed was $2.13 \mathrm{~m} \cdot \mathrm{s}^{-1}$, which was $15 \%$ higher than that $\left(1.85 \mathrm{~m} \cdot \mathrm{s}^{-1}\right)$ for $-1.0<\mathrm{CBO}<-0.5$. While $0.5<\mathrm{CBO}<1.0$, the seasonal differences of wind speed 
were obvious. The diurnal variations in autumn and winter showed apparent single peak pattern as $-1.0<\mathrm{CBO}<-0.5$, while the peak happened in advance (around 10:00). The peaking values in autumn and winter were both higher than those for $-1.0<\mathrm{CBO}<-0.5$ and especially, the highest wind speed in winter $\left(3.95 \mathrm{~m} \cdot \mathrm{s}^{-1}\right)$ was $50 \%$ higher than that $\left(2.69 \mathrm{~m} \cdot \mathrm{s}^{-1}\right)$ for $-1.0<\mathrm{CBO}<-0.5$. Conversely, the diurnal variations in spring and summer did not show apparent single peak pattern as $-1.0<\mathrm{CBO}<-0.5$ and fluctuated widely at a relatively high level (spring: $3.10 \mathrm{~m} \cdot \mathrm{s}^{-1}$, summer: $2.46 \mathrm{~m} \cdot \mathrm{s}^{-1}$ ).

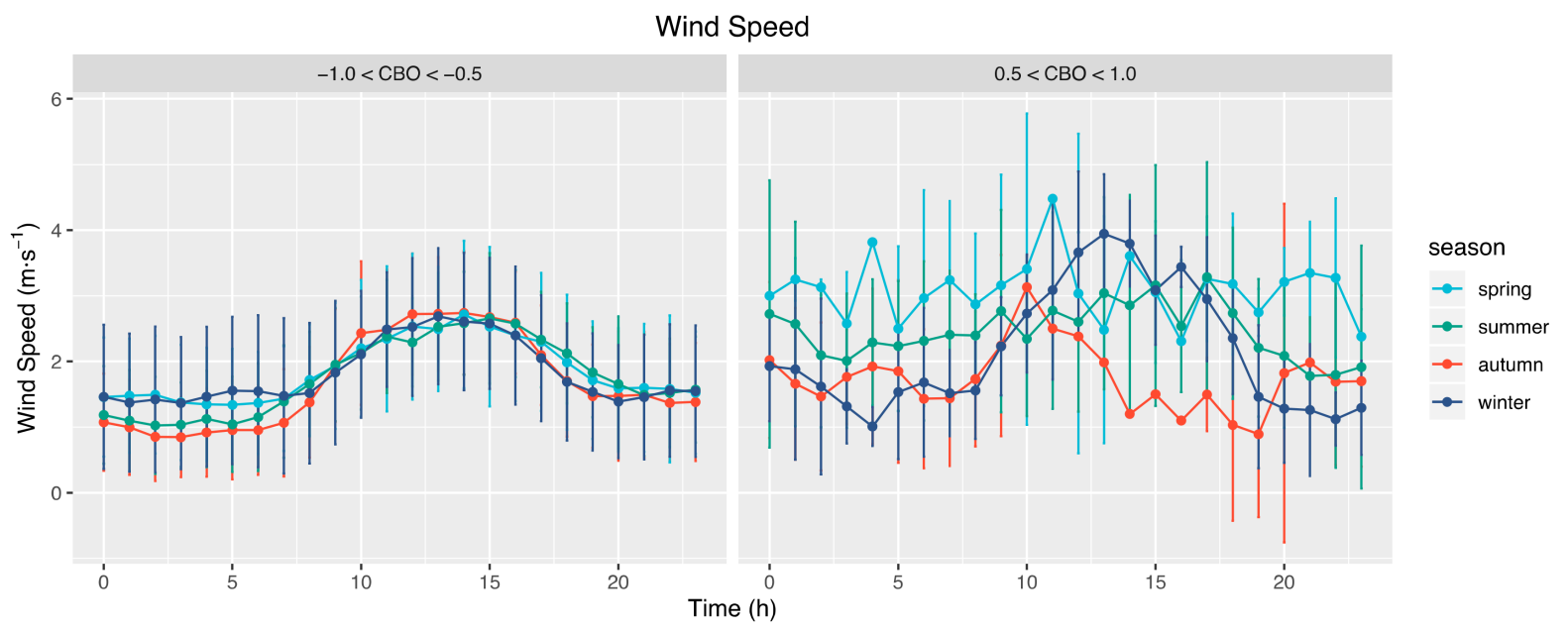

Figure 12. Diurnal variations of wind speed in two situations: (left): $-1.0<\mathrm{CBO}<-0.5$ and (right): $0.5<\mathrm{CBO}<1.0$.

Apart from wind speed, relative humidity differed in two situations. As shown in Figure $13,(1)$ while $-1.0<\mathrm{CBO}<-0.5$, diurnal variations of relative humidity $(\mathrm{RH})$ rose at 0:00-6:00, 15:00-23:00 and dropped at 6:00-15:00, reaching a minimum at around 15:00. The minimum was $32.04 \%, 49.99 \%, 48.07 \%$ and $40.74 \%$ in spring, summer, autumn and winter, respectively. (2) While $0.5<\mathrm{CBO}<1.0$, except for spring, the diurnal variations of $\mathrm{RH}$ in the other three seasons showed the similar pattern as $-1.0<\mathrm{CBO}<-0.5$, but the minimums $(62.29 \%$ in spring, 69.00\% in autumn, 54.95\% in winter) were much higher than those for $-1.0<\mathrm{CBO}<-0.5$. While $0.5<\mathrm{CBO}<1.0$, the amplitude of diurnal variations of $\mathrm{RH}$ was smaller, which means RH was more stable. The most apparent difference between the two situations was in spring. The minimum $\mathrm{RH}$ in spring was merely $31.02 \%$, lower than that for $-1.0<\mathrm{CBO}<-0.5$. What is more, the average RH $(63.19 \%)$ during 0:00-9:00 in spring was much lower than that $(45.04 \%)$ for $-1.0<\mathrm{CBO}<-0.5$.

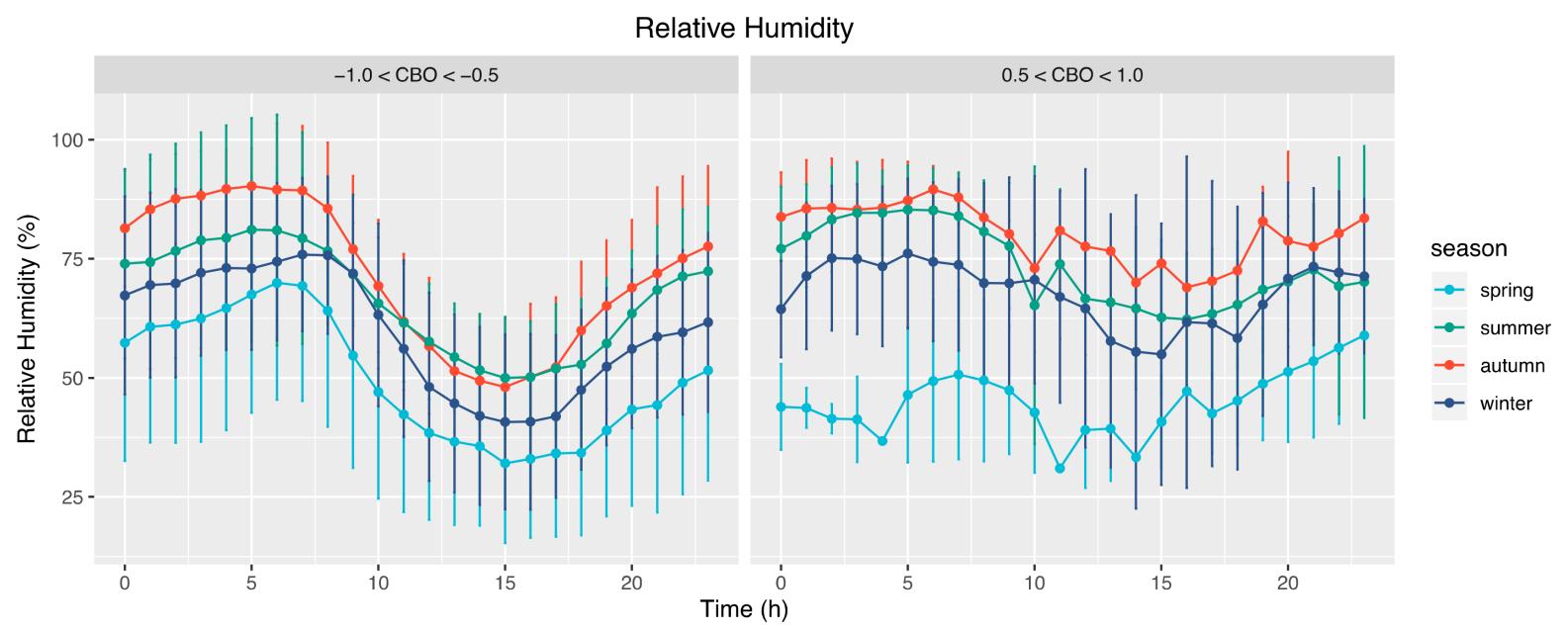

Figure 13. Diurnal variations of relative humidity in two situations: (left): $-1.0<\mathrm{CBO}<-0.5$ and (right): $0.5<\mathrm{CBO}<1.0$. 
Compared with wind speed and $\mathrm{RH}$, the differences of visibility between two situations were relatively small. As shown in Figure 14 , (1) while $-1.0<\mathrm{CBO}<-0.5$, diurnal variations of visibility showed a single peak pattern, reaching the maximum at around 16:00 in spring $(13.10 \mathrm{~km})$ and summer $(14.90 \mathrm{~km})$, and around 14:00-15:00 in autumn $(14.22 \mathrm{~km})$ and winter $(9.85 \mathrm{~km})$. The average visibility was the highest in summer, second in spring and autumn, and the lowest in winter. (2) While $0.5<\mathrm{CBO}<1.0$, the amplitude of diurnal variations of visibility was smaller than that for $-1.0<\mathrm{CBO}<-0.5$. Especially in spring and winter, visibility fluctuated at the level of around $8 \mathrm{~km}$ with an aptitude of about $1 \mathrm{~km} / \mathrm{h}$.

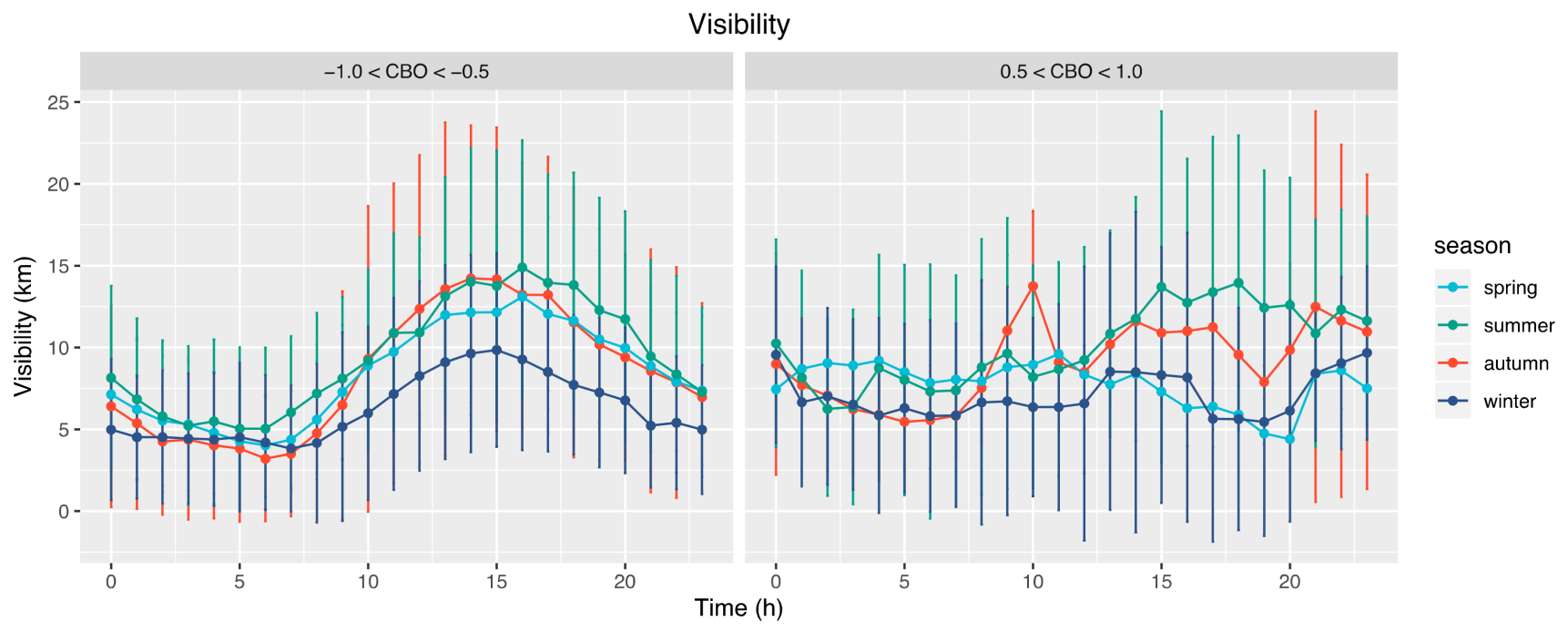

Figure 14. Diurnal variations of visibility in two situations: (left): $-1.0<\mathrm{CBO}<-0.5$ and (right): $0.5<\mathrm{CBO}<1.0$.

\section{Conclusions}

This study utilized the data of pollutant concentrations ( $\mathrm{BC}, \mathrm{O}_{3}, \mathrm{PM}_{2.5}, \mathrm{PM}_{10}, \mathrm{CO}, \mathrm{NO}_{2}$ and $\mathrm{SO}_{2}$ ) and meteorological elements during 2015 to 2018 in Nanjing, China to analyze the daily correlation between black carbon and ozone (CBO). Samples (6988) with significantly negative $\mathrm{CBO}$ collected are much more than those (403) with significant positive CBO. However, the frequency analysis of $\mathrm{CBO}$ showed that the proportion of high positive $\mathrm{CBO}$ had been increasing annually, with an average increasing rate of $7.1 \% /$ year. The proportion of significantly positive $\mathrm{CBO}(0.5<\mathrm{CBO}<0.8)$ in summer was $38.7 \%$ on average, nearly twice of that in the other seasons (19.2\%). The analysis of the distribution of the pollutant concentrations under different levels of $\mathrm{CBO}$ showed that the average $\mathrm{BC}, \mathrm{PM}_{2.5}$ and $\mathrm{NO}_{2}$ concentrations under positive $\mathrm{CBO}$ were lower than those under negative $\mathrm{CBO}$. However, the difference of average ozone concentrations between such two situations was not apparent. It is noticeable that the surface ozone began to ascend when $\mathrm{CBO}$ was up to 0.2 , with $\mathrm{PM}_{2.5}$ and $\mathrm{NO}_{2}$ decreasing and $\mathrm{BC}$ steady.

Besides, the diurnal variations of pollutant concentrations and meteorological elements between two situations were also compared. Under negative $\mathrm{CBO}$, pollutant concentrations and meteorological elements showed obvious modes of diurnal variations: $\mathrm{BC}$ showed a double-peak pattern, surface ozone, $\mathrm{PM}_{2.5}, \mathrm{SO}_{2}$ and $\mathrm{CO}$ showed single-peak patterns and $\mathrm{NO}_{2}$ showed a trough from 10:00 to 19:00. Wind speed and visibility showed a single-peak pattern with little seasonal difference. Relative humidity rose first, then lowered and then rose. While under positive $\mathrm{CBO}$, the above patterns of diurnal variations became less obvious and some of them even showed no patterns, but just fluctuated at a certain level. Under positive $\mathrm{CBO}, \mathrm{BC}$ was stable during 0:00-13:00, fluctuating slightly around $1.40 \mu \mathrm{g} \cdot \mathrm{m}^{-3}$, which was merely half of that $\left(3.0 \mu \mathrm{g} \cdot \mathrm{m}^{-3}\right)$ during the contemporaneous period under negative $\mathrm{CBO}$ and the trend after 13:00 differed significantly in different seasons. Under negative $\mathrm{CBO}$, the peaks of $\mathrm{O}_{3}$ in summer and autumn declined obviously 
and those in spring and winter increased obviously compared with those under negative $\mathrm{CBO}$. Besides, the overall $\mathrm{NO}_{2}$ concentrations were lower and the overall wind speed was higher under positive $\mathrm{CBO}$. The diurnal fluctuation of relative humidity and visibility was smaller under positive CBO.

Supplementary Materials: The following are available online at https: / www.mdpi.com/article / 10.3390 /atmos12050626/s1, Figure S1: Mass concentrations of pollutants $\left(\mathrm{SO}_{2}, \mathrm{PM}_{10}, \mathrm{CO}\right)$ and meteorological elements (Visibility, Relative Humidity, Wind Speed) under different levels of CBO.

Author Contributions: Conceptualization, Y.T., D.Z., H.W. and B.Z.; data curation, D.Z., A.L. and S.S.; formal analysis, Y.T.; methodology, Y.T.; supervision, H.W. and B.Z.; writing—original draft, Y.T.; writing-review and editing, Y.T., H.W., D.B., A.L., S.S. and Q.D. All authors have read and agreed to the published version of the manuscript.

Funding: This research was funded by the National Key Research and Development Program of China, grant number 2016YFA0602001, the National Natural Science Foundation of China, grant number 41805096 and the China Postdoctoral Science Foundation, grant number 2018M640169.

Institutional Review Board Statement: Not applicable.

Informed Consent Statement: Not applicable.

Data Availability Statement: The ground observation data are available from the authors upon request.

Conflicts of Interest: The authors declare no conflict of interest.

\section{References}

1. Hvidtfeldt, U.A.; Sørensen, M.; Geels, C.; Ketzel, M.; Khan, J.; Tjønneland, A.; Overvad, K.; Brandt, J.; Raaschou-Nielsen, O. Long-term residential exposure to PM2.5, PM10, black carbon, NO2, and ozone and mortality in a Danish cohort. Environ. Int. 2019, 123, 265-272. [CrossRef] [PubMed]

2. Wang, Y.; Wild, O.; Chen, X.; Wu, Q.; Gao, M.; Chen, H.; Qi, Y.; Wang, Z. Health impacts of long-term ozone exposure in China over 2013-2017. Environ. Int. 2020, 144, 106030. [CrossRef]

3. Mahmood, F.; Khokhar, M.F.; Mahmood, Z. Examining the relationship of tropospheric ozone and climate change on crop productivity using the multivariate panel data techniques. J. Environ. Manag. 2020, 272, 111024. [CrossRef]

4. de Foy, B.; Brune, W.H.; Schauer, J.J. Changes in ozone photochemical regime in Fresno, California from 1994 to 2018 deduced from changes in the weekend effect. Environ. Pollut. 2020, 263, 114380. [CrossRef]

5. Jenkin, M.E.; Derwent, R.G.; Wallington, T.J. Photochemical ozone creation potentials for volatile organic compounds: Rationalization and estimation. Atmos. Environ. 2017, 163, 128-137. [CrossRef]

6. Robinson, J.; Kotsakis, A.; Santos, F.; Swap, R.; Knowland, K.E.; Labow, G.; Connors, V.; Tzortziou, M.; Abuhassan, N.; Tiefengraber, M.; et al. Using networked Pandora observations to capture spatiotemporal changes in total column ozone associated with stratosphere-to-troposphere transport. Atmos. Res. 2020, 238, 104872. [CrossRef]

7. Tarasick, D.W.; Carey-Smith, T.K.; Hocking, W.K.; Moeini, O.; He, H.; Liu, J.; Osman, M.K.; Thompson, A.M.; Johnson, B.J.; Oltmans, S.J.; et al. Quantifying stratosphere-troposphere transport of ozone using balloon-borne ozonesondes, radar windprofilers and trajectory models. Atmos. Environ. 2019, 198, 496-509. [CrossRef]

8. Farooqui, Z.M.; John, K.; Biswas, J.; Sule, N. Modeling analysis of the impact of anthropogenic emission sources on ozone concentration over selected urban areas in Texas. Atmos. Pollut. Res. 2013, 4, 33-42. [CrossRef]

9. Im, U.; Poupkou, A.; Incecik, S.; Markakis, K.; Kindap, T.; Unal, A.; Melas, D.; Yenigun, O.; Topcu, S.; Odman, M.T.; et al. The impact of anthropogenic and biogenic emissions on surface ozone concentrations in Istanbul. Sci. Total Environ. 2011, 409, 1255-1265. [CrossRef]

10. Liu, P.; Song, H.; Wang, T.; Wang, F.; Li, X.; Miao, C.; Zhao, H. Effects of meteorological conditions and anthropogenic precursors on ground-level ozone concentrations in Chinese cities. Environ. Pollut. 2020, 262, 114366. [CrossRef]

11. Ryu, Y.-H.; Baik, J.-J.; Lee, S.-H. Effects of anthropogenic heat on ozone air quality in a megacity. Atmos. Environ. 2013, 80, 20-30. [CrossRef]

12. Ma, Y.; Ma, B.; Jiao, H.; Zhang, Y.; Xin, J.; Yu, Z. An analysis of the effects of weather and air pollution on tropospheric ozone using a generalized additive model in Western China: Lanzhou, Gansu. Atmos. Environ. 2020, 224, 117342. [CrossRef]

13. Liu, Y.; Wang, T. Worsening urban ozone pollution in China from 2013 to 2017-Part 1: The complex and varying roles of meteorology. Atmos. Chem. Phys. 2020, 20, 6305-6321. [CrossRef]

14. Bond, T.C.; Doherty, S.J.; Fahey, D.W.; Forster, P.M.; Berntsen, T.; DeAngelo, B.J.; Flanner, M.G.; Ghan, S.; Kärcher, B.; Koch, D.; et al. Bounding the role of black carbon in the climate system: A scientific assessment: Black Carbon in the Climate System. J. Geophys. Res. Atmos. 2013, 118, 5380-5552. [CrossRef] 
15. Pani, S.K.; Wang, S.-H.; Lin, N.-H.; Chantara, S.; Lee, C.-T.; Thepnuan, D. Black carbon over an urban atmosphere in northern peninsular Southeast Asia: Characteristics, source apportionment, and associated health risks. Environ. Pollut. 2020, $259,113871$. [CrossRef]

16. Lin, W.; Dai, J.; Liu, R.; Zhai, Y.; Yue, D.; Hu, Q. Integrated assessment of health risk and climate effects of black carbon in the Pearl River Delta region, China. Environ. Res. 2019, 176, 108522. [CrossRef] [PubMed]

17. Gu, Y.; Zhang, W.; Yang, Y.; Wang, C.; Streets, D.G.; Yim, S.H.L. Assessing outdoor air quality and public health impact attributable to residential black carbon emissions in rural China. Resour. Conserv. Recycl. 2020, 159, 104812. [CrossRef]

18. Ji, D.; Gao, W.; Maenhaut, W.; He, J.; Wang, Z.; Li, J.; Du, W.; Wang, L.; Sun, Y.; Xin, J.; et al. Impact of air pollution control measures and regional transport on carbonaceous aerosols in fine particulate matter in urban Beijing, China: Insights gained from long-term measurement. Atmos. Chem. Phys. 2019, 19, 8569-8590. [CrossRef]

19. Kucbel, M.; Corsaro, A.; Švédová, B.; Raclavská, H.; Raclavský, K.; Juchelková, D. Temporal and seasonal variations of black carbon in a highly polluted European city: Apportionment of potential sources and the effect of meteorological conditions. J. Environ. Manag. 2017, 203, 1178-1189. [CrossRef]

20. Bibi, S.; Alam, K.; Chishtie, F.; Bibi, H.; Rahman, S. Temporal variation of Black Carbon concentration using Aethalometer observations and its relationships with meteorological variables in Karachi, Pakistan. J. Atmos. Sol.-Terr. Phys. 2017, 157-158, 67-77. [CrossRef]

21. Bai, Z.; Cui, X.; Wang, X.; Xie, H.; Chen, B. Light absorption of black carbon is doubled at Mt. Tai and typical urban area in North China. Sci. Total Environ. 2018, 635, 1144-1151. [CrossRef]

22. Ma, Y.; Huang, C.; Jabbour, H.; Zheng, Z.; Wang, Y.; Jiang, Y.; Zhu, W.; Ge, X.; Collier, S.; Zheng, J. Mixing state and light absorption enhancement of black carbon aerosols in summertime Nanjing, China. Atmos. Environ. 2020, 222, 117141. [CrossRef]

23. Xie, C.; Xu, W.; Wang, J.; Liu, D.; Ge, X.; Zhang, Q.; Wang, Q.; Du, W.; Zhao, J.; Zhou, W.; et al. Light absorption enhancement of black carbon in urban Beijing in summer. Atmos. Environ. 2019, 213, 499-504. [CrossRef]

24. Zhang, B.-N.; Kim Oanh, N.T. Photochemical smog pollution in the Bangkok Metropolitan Region of Thailand in relation to O3 precursor concentrations and meteorological conditions. Atmos. Environ. 2002, 36, 4211-4222. [CrossRef]

25. Hu, D.; Chen, Y.; Wang, Y.; Daële, V.; Idir, M.; Yu, C.; Wang, J.; Mellouki, A. Photochemical reaction playing a key role in particulate matter pollution over Central France: Insight from the aerosol optical properties. Sci. Total Environ. 2019, 657, 1074-1084. [CrossRef]

26. Li, G.; Zhang, R.; Fan, J.; Tie, X. Impacts of black carbon aerosol on photolysis and ozone. J. Geophys. Res. Atmos. 2005, 110. [CrossRef]

27. Gao, J.; Zhu, B.; Xiao, H.; Kang, H.; Pan, C.; Wang, D.; Wang, H. Effects of black carbon and boundary layer interaction on surface ozone in Nanjing, China. Atmos. Chem. Phys. 2018, 18, 7081-7094. [CrossRef]

28. Lu, X.; Zhang, L.; Chen, Y.; Zhou, M.; Zheng, B.; Li, K.; Liu, Y.; Lin, J.; Fu, T.-M.; Zhang, Q. Exploring 2016-2017 surface ozone pollution over China: Source contributions and meteorological influences. Atmos. Chem. Phys. 2019, 19, 8339-8361. [CrossRef]

29. Shen, L.; Jacob, D.J.; Liu, X.; Huang, G.; Li, K.; Liao, H.; Wang, T. An evaluation of the ability of the Ozone Monitoring Instrument (OMI) to observe boundary layer ozone pollution across China: Application to 2005-2017 ozone trends. Atmos. Chem. Phys. 2019, 19, 6551-6560. [CrossRef]

30. Tan, Y.; Wang, H.; Shi, S.; Shen, L.; Zhang, C.; Zhu, B.; Guo, S.; Wu, Z.; Song, Z.; Yin, Y.; et al. Annual variations of black carbon over the Yangtze River Delta from 2015 to 2018. J. Environ. Sci. 2020, 96, 72-84. [CrossRef] [PubMed]

31. Lu, X.; Hong, J.; Zhang, L.; Cooper, O.R.; Schultz, M.G.; Xu, X.; Wang, T.; Gao, M.; Zhao, Y.; Zhang, Y. Severe Surface Ozone Pollution in China: A Global Perspective. Environ. Sci. Technol. Lett. 2018, 5, 487-494. [CrossRef]

32. Xie, Y.; Dai, H.; Zhang, Y.; Wu, Y.; Hanaoka, T.; Masui, T. Comparison of health and economic impacts of PM2.5 and ozone pollution in China. Environ. Int. 2019, 130, 104881. [CrossRef] [PubMed]

33. Drinovec, L.; Močnik, G.; Zotter, P.; Prévôt, A.S.H.; Ruckstuhl, C.; Coz, E.; Rupakheti, M.; Sciare, J.; Müller, T.; Wiedensohler, A.; et al. The "dual-spot" Aethalometer: An improved measurement of aerosol black carbon with real-time loading compensation. Atmos. Meas. Tech. 2015, 8, 1965-1979. [CrossRef]

34. Putero, D.; Cristofanelli, P.; Marinoni, A.; Adhikary, B.; Duchi, R.; Shrestha, S.D.; Verza, G.P.; Landi, T.C.; Calzolari, F.; Busetto, M.; et al. Seasonal variation of ozone and black carbon observed at Paknajol, an urban site in the Kathmandu Valley, Nepal. Atmos. Chem. Phys. 2015, 15, 13957-13971. [CrossRef]

35. Ran, L.; Deng, Z.Z.; Wang, P.C.; Xia, X.A. Black carbon and wavelength-dependent aerosol absorption in the North China Plain based on two-year aethalometer measurements. Atmos. Environ. 2016, 142, 132-144. [CrossRef]

36. Ravi Kiran, V.; Talukdar, S.; Venkat Ratnam, M.; Jayaraman, A. Long-term observations of black carbon aerosol over a rural location in southern peninsular India: Role of dynamics and meteorology. Atmos. Environ. 2018, 189, 264-274. [CrossRef] 